\title{
Living with a crab: effect of Austinotheres angelicus (Brachyura, Pinnotheridae) infestation on the condition of Saccostrea palmula (Ostreoida, Ostreidae)
}

\author{
Sebastián Mena, Carolina Salas-Moya and Ingo S. Wehrtmann
}

(SM, CSM, ISW) Escuela de Biología, Universidad de Costa Rica, 11501-2060 San José, Costa Rica. E-mails: (SM) sebas.menago@gmail.com; (CSM) caro.salasm@gmail.com

(ISW) UNIP (Unidad de Investigación Pesquera y Acuicultura), CIMAR (Centro de Investigación en Ciencias del Mar y Limnología), Universidad de Costa Rica, 11501-2060 San José, Costa Rica. E-mail: ingowehrtmann@gmx.de

\begin{abstract}
Some members of the Pinnotheridae family exhibit close symbiotic relationships with bivalves, which may cause severe damage to the mollusk. The condition index $(\mathrm{CI})$ is a tool that serves to evaluate the effect of biotic and abiotic factors on the morphology and physiology of mollusks, including those caused by symbiotic organisms. In the present study, we evaluated the effects of the infestation of the pinnotherid crab Austinotheres angelicus on the oyster Saccostrea palmula through monthly sampling (April to November 2012) in Punta Morales, Pacific coast of Costa Rica. A total of 245 oysters were analyzed, of which 38\% were infested by the pinnotherid crab. Most of the oysters analyzed (92\%) varied in depth between 1.5 and $15.0 \mathrm{~mm} ; 89 \%$ of the infested oysters were in this depth range. The prevalence was positively correlated with the depth of the oyster. Our results revealed that crab infestation could reduce the CI by 11 to $33 \%$. The obtained findings suggest that the infestation by $A$. angelicus provokes alterations of the flesh production of the oyster, especially when the association is with a pair of crabs including an ovigerous female. The association of $A$. angelicus with $S$. palmula is best described as facultative parasitism for male crabs and obligatory parasitism for females.
\end{abstract}

Key Words: Fitness, interaction, parasitism, pea crab, symbiosis

\section{INTRODUCTION}

Pinnotherid crabs are small decapods that live in association with a large variety of invertebrates, such as ascideans, brachiopods, axiid shrimps, echinoderms, polychaetes, gastropods and bivalves (Rathbun, 1900; Campos, 1990, 1996, 2002; Feldmann et al., 1996; Grove and Woodin, 1996; Geiger and Martin, 1999; Ng and Manning, 2003; Peiró and Mantelatto, 2011). Several authors considered some species as commensals (Feldmann et al., 1996; Baeza, 1999; Mantelatto and Cuesta, 2010), while others refer to other species as parasites, especially those living associated with to bivalves (Kruczinsky, 1972, 1975; Bierbaum and Ferson, 1986; Bierbaum and Shumway, 1988; Trottier et al., 2012).

Aspects of the ecological interactions between pinnotherids and bivalves have been well studied, due to the economic importance of many of these mollusks (Kruczynski, 1972, 1975; Bierbaum and Ferson, 1986; Bierbaum and Shumway, 1988; Cabrera Peña etal., 2001b; Mercado-Silva, 2005; Sun et al., 2006; Trottier et al., 2012). However, our understanding of the ecological relationships within the 
family Pinnotheridae is far from complete. Pinnotherids, which feed on particles that have been filtered and accumulated in the mucus by the host, usually a bivalve, are perhaps the most well-known marine kleptoparasites (Iyengar, 2008). Such a behavior causes an alteration in the mollusk's growth due to a reduction in food availability (Kruszynski, 1975). However, pinnotherids can provoke injuries in the gills (Kruszynski, 1975), which reduce both filtration and oxygen consumption rates (Bierbaum and Ferson, 1986; Bierbaum and Shumway, 1988). These relationships cannot be defined as kleptoparasitism because the host suffers damages that go beyond the mere food loss (Iyengar, 2008).

The association between pinnotherid crabs and mollusks may cause negative effects on the biomass and morphology on the latter (Kruczynski, 1972; Mercado-Silva, 2005). The magnitude of these consequences is often difficult to assess or sometimes even undetermined (Zapalski, 2011). Because of this situation, the implementation of adequate ecological indicators is important (Filgueira et al., 2013). The condition index (CI), one of those indicators, is a mathematical method used to determine the health status of bivalves (Austin et al., 1993; Mercado-Silva, 2005; Sun et al., 2006; Filgueira et al., 2013). Just as other health indicators, the CI relates the biomass with some other variable correlated to bivalve's size (Froese, 2006). Some authors have used the CI to assess the effects of the association between pinnotherids and their bivalve hosts (Mercado-Silva, 2006; Sun et al., 2006).

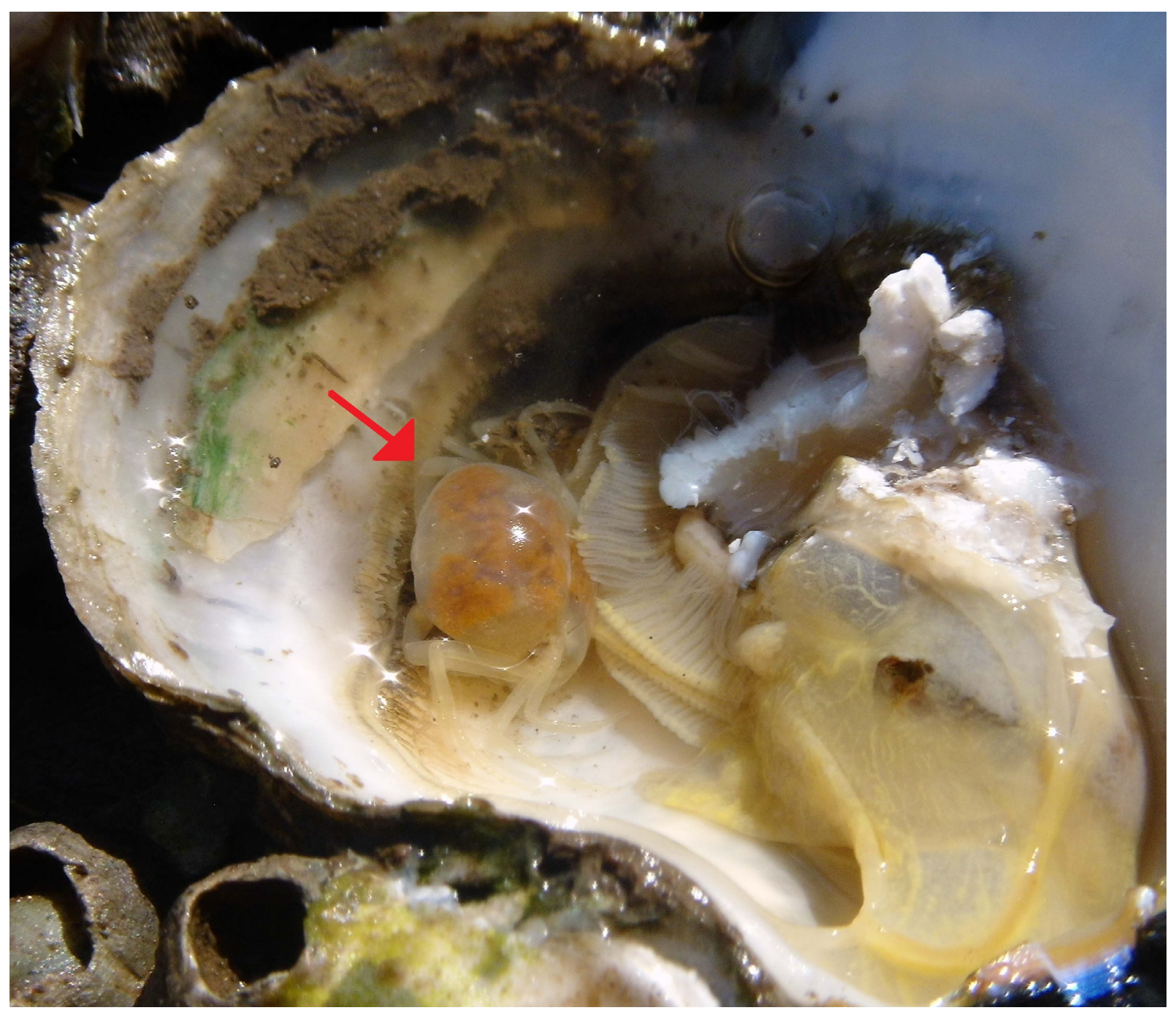

Figure 1. Female Austinotheres angelicus (indicated by red arrow) inside of the oyster Saccostrea palmula, Punta Morales, Golfo de Nicoya, Pacific coast of Costa Rica. 
The genus Austinotheres was described by Campos (2002), and can be distinguished from other pinnotherids by the morphology of the third maxilliped; moreover, the second pair of pereopods is asymmetric. The pea crab Austinotheres angelicus (Lockington, 1877) is the only described species of the genus. The species is distributed along the Eastern Tropical Pacific, from the Gulf of California, Mexico, to the Colombian coast, and can be found up to $200 \mathrm{~m}$ in depth (Lemaitre and Alvarez León, 1992). So far, this pinnotherid crab has been observed as a symbiont of bivalves in the Ostrea, Myrakeena and Saccostrea genera (Campos, 2002; Campos and Vargas-Castillo, 2014; Salas-Moya et al., 2014). Different aspects of the ecology of the species have been studied by Cabrera Peña et al. (2011a, b) and Salas-Moya et al. (2014). In the present study $A$. angelicus was found in association with Saccostrea palmula (Carpenter, 1857), an oyster that lives in mangrove systems and rocky intertidal areas along the Eastern Tropical Pacific from Baja California Sur to Panama and the Galápagos Islands (Harry, 1985). Cabrera Peña et al. (2001a) studied some biometric variables of $S$. palmula (including a definition of $\mathrm{CI}$ ); however, the effect of intensity and sex of pea crabs on the health of $S$. palmula remained unclear. Recently, Salas-Moya et al. (2014) documented that $A$. angelicus invested a high amount of energy in offspring production (Salas-Moya et al., 2014). Since female weight increases considerably during reproduction, they can cause more damage to the oyster than the substantially smaller males (Sun et al., 2006).

Data about the costs of $S$. palmula hosting the pinnotherid crab are lacking in the scientific literature. In the present study, we quantified the effects of the interaction between the pinnotherid crab $A$. angelicus and the condition of its host, $S$. palmula in Punta Morales, Pacific coast of Costa Rica (Fig. 1). Our study provides information on the infestation of $A$. angelicus, and how their number and sex influence the health of the bivalve host.

\section{Material and Methods}

Study site

The study was carried out in Punta Morales, which is located in the northeastern area of the Gulf of Nicoya, Pacific coast of Costa Rica (Fig. 2). Samples were collected along the rocky intertidal zone of Playa Blanca and in the Estero Morales river mouth. The dry season extends from December to March, followed by a transition period (April to May), while the rainy season lasts from June to November (Brugnoli Olivera and Morales Ramírez, 1999).

\section{Sampling}

Monthly samples were taken between April and November 2012. At least 30 oysters were collected from the intertidal zone during each sampling. Collected oysters were stored in individual bags filled with $70 \%$ ethanol. The material was analyzed in the laboratory of the Unidad de Investigación Pesquera y Acuicultura (UNIP) of the Centro de Investigación en Ciencias del Mar y Limnología (CIMAR), Universidad de Costa Rica (UCR), San José. In the laboratory, oysters were cleaned of epizoic organisms, and maximum depth (maximum distance between the outer and surfaces of the two shells; Loosanoff and Nomejko, 1949) was measured. After opening the oyster with a forceps and scalpel, the bivalve was inspected for the presence of Austinotheres angelicus individuals using a compound stereoscope. We counted the associated crabs and categorized them as female $(\mathrm{F})$, ovigerous female $(\mathrm{OF})$ or male (M). Maximum depth and gravimetric variables were measured with an electronic caliper $( \pm 0.01 \mathrm{~mm})$ and an analytic balance $( \pm 0.0001 \mathrm{~g})$, respectively. In order to obtain the dry weight of the shell and the flesh of the oysters, both parts were dried in an oven at $60^{\circ} \mathrm{C}$ for 48 hours.

\section{Data analysis}

"Prevalence" refers to the percentage of infested oysters, and "intensity" indicates the number of crabs per infested oyster (Sun et al., 2006). 


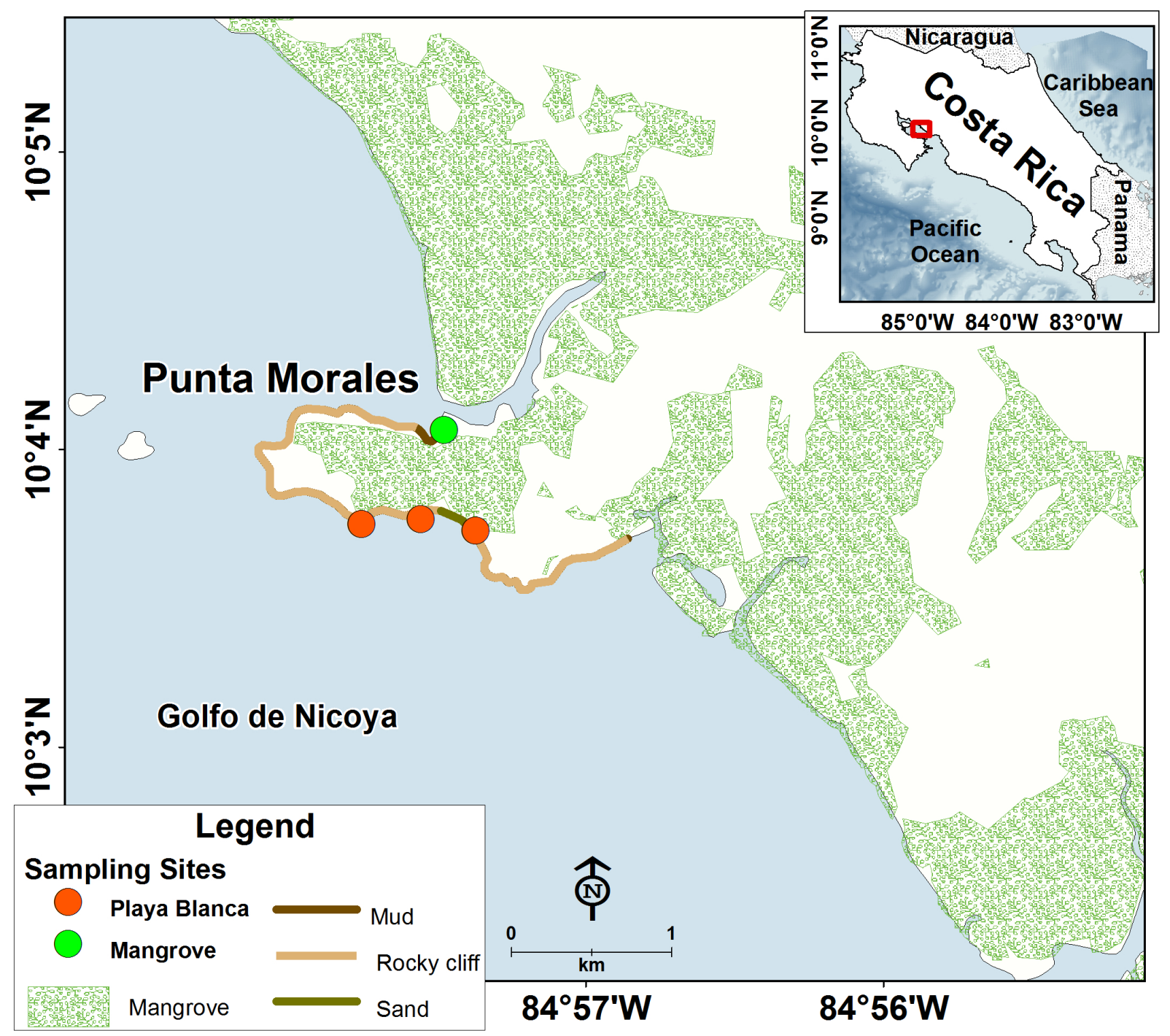

Figure 2. Sampling locations in Punta Morales, Golfo de Nicoya, Pacific coast of Costa Rica.

The oyster depth was used to generate depths-frequency distributions of both infested and non-infested oysters. In order to determine if the frequency of the oyster explains the pea crab prevalence observed, we calculated the coefficient of determination for the linear relation between pea crab prevalence and frequency of oysters for each size. The same procedure was applied to assess the relation between the depth of the bivalve and the variability of the prevalence.

To quantify the effect of the associated crabs regarding the flesh of the oysters, we calculated the percent meat yield or Condition Index $(\mathrm{CI})$, which indicates better conditions at higher values, according to the following equation (Sun et al., 2006):

$\mathrm{CI}(\%)=\frac{\text { Dry meat weight }(\mathrm{g})}{\text { Dry meat weight }(\mathrm{g})+\operatorname{Dry} \text { shell weight }(\mathrm{g})} * 100$
A Kruskal-Wallis test was used to compare the CI between different oyster depths. Subsequently and using the same test, we compared CI values between non-infested and infested oysters; in the latter case we analyzed the following categories of infestation: oyster not infested $(\mathrm{O})$, oysters infested by males $(\mathrm{M})$, by non-ovigerous adult females (F), by ovigerous females (OF), by heterosexual pairs with a non-ovigerous adult female $(\mathrm{F}+\mathrm{M})$, and heterosexual pairs with ovigerous females $(\mathrm{OF}+\mathrm{M})$. Student's t-tests were conducted to identify the category of infestation that affected most the CI. All statistical analyses were carried out with the program JMP version 7.0. Finally, we estimated the percent decrease of the $\mathrm{CI}$ for the different categories of infestation based on average $\mathrm{CI}$ of not infested oysters. 


\section{Results}

A total of 245 oysters were analyzed, of which 38\% (93 ind.) were infested by Austinotheres angelicus. Average crab intensity was of $1.62 \pm$ $0.53 \mathrm{crab} /$ oyster. Most of the infested oysters (83 ind.; 89\%) fluctuated between 4.5 to $15.0 \mathrm{~mm}$ in depth (Tab. 1). The prevalence of infested oysters was not explained by the frequency of the host per depth $\left(\mathrm{R}^{2}=0.08\right.$; Tab. 1). The oyster depth, however, explained $60 \%$ of the prevalence variability (Tab. 1 ).

Significant differences were detected between the CI values and depth $\left(\chi^{2}=20.86\right.$, d.f. $=7, p=0.004$; Tab. 1; Fig. 3). There were significant differences between CI values across infestation categories $\left(\chi^{2}=55.84\right.$, d.f. $=5, \mathrm{p}$ $<0.0001$ ) (Tab. 2; Fig. 4). The infestation by pinnotherid pairs significantly reduced the CI values, in the case of both non-ovigerous ( $\mathrm{p}<$ $0.002)$ and ovigerous females $(p<0.0001)$. The presence of ovigerous females in the absence of

Table 1. Saccostrea palmula and Austinotheres angelicus: Variation of oyster frequency and pea crab prevalence according to oyster's depth, in Punta Morales, Pacific coast of Costa Rica.

\begin{tabular}{ccccc}
\hline Depth $(\mathrm{mm})$ & $\mathrm{n}$ & $\begin{array}{c}\text { Oyster } \\
\text { frequency }\end{array}$ & $\begin{array}{c}\text { Infested } \\
\text { oysters }\end{array}$ & $\begin{array}{c}\text { Pea crab } \\
\text { prevalence }\end{array}$ \\
\hline $4.5-6.6$ & 9 & 3.7 & 1 & $11 \%$ \\
$6.7-8.7$ & 42 & 17.1 & 6 & $14 \%$ \\
$8.8-10.8$ & 68 & 27.8 & 24 & $35 \%$ \\
$10.9-12.9$ & 70 & 28.6 & 33 & $47 \%$ \\
$13.0-15.0$ & 37 & 15.1 & 19 & $51 \%$ \\
$15.1-17.1$ & 14 & 5.7 & 6 & $43 \%$ \\
$17.2-19.2$ & 3 & 1.2 & 3 & $100 \%$ \\
$19.3-21.3$ & 2 & 0.8 & 1 & $50 \%$ \\
\hline
\end{tabular}

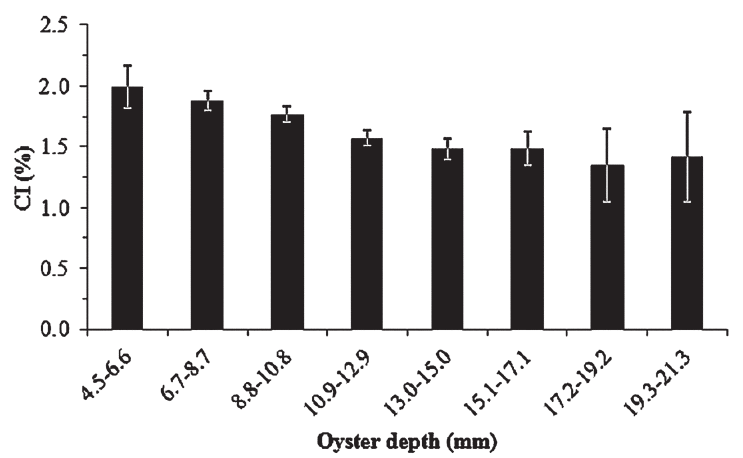

Figure 3. Saccostrea palmula: Variation of the Condition Index (CI) according to the oyster depth in Punta Morales, Pacific coast of Costa Rica. Bars show standard error. males did not alter the CI values $(\mathrm{p}=0.09)$, while the infestation of single non-ovigerous females significantly reduced the CI values ( $p$ $=0.005)$. Males did not significantly affect the CI values $(p=0.18)$. Percent decrease of the CI for the different categories of infestation was summarized in Table 2.

Table 2. Saccostrea palmula and Austinotheres angelicus: Number of analyzed oysters (n), average Condition Index (CI), standard error (SE), and percent decrease according to the infestation categories (0: not infested; $\mathrm{M}$ : male infestation; F: infestation of adult females without embryos; OF: infested by ovigerous females; F+M: infested by adult females without embryos together with males; $\mathrm{OF}+\mathrm{M}$ : infested by ovigerous females with males), in Punta Morales, Pacific coast of Costa Rica.

\begin{tabular}{lcccc}
\hline $\begin{array}{c}\text { Categories of } \\
\text { infestation }\end{array}$ & $\mathrm{n}$ & $\mathrm{CI}$ & $\mathrm{SE}$ & $\begin{array}{c}\text { Percent } \\
\text { decrease }\end{array}$ \\
\hline 0 & 155 & 1.80 & 0.04 & $0 \%$ \\
$\mathrm{M}$ & 9 & 1.60 & 0.15 & $11 \%$ \\
$\mathrm{~F}$ & 22 & 1.51 & 0.07 & $16 \%$ \\
$\mathrm{OF}$ & 2 & 1.24 & 0.34 & $31 \%$ \\
$\mathrm{~F}+\mathrm{M}$ & 12 & 1.37 & 0.17 & $24 \%$ \\
$\mathrm{OF}+\mathrm{M}$ & 44 & 1.21 & 0.06 & $33 \%$ \\
\hline
\end{tabular}

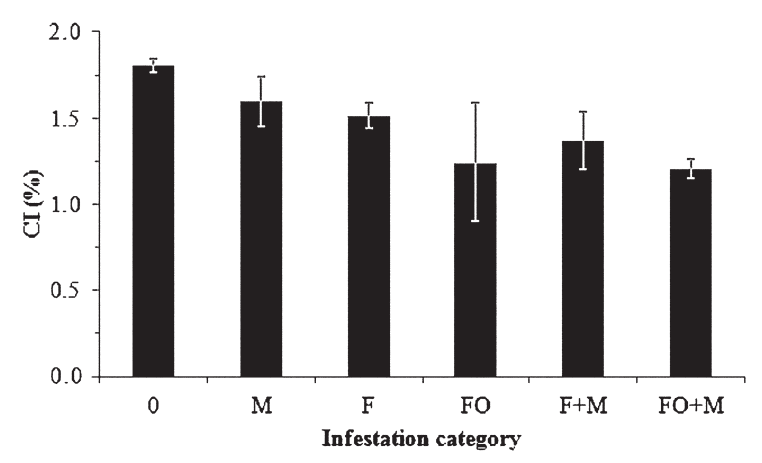

Figure 4. Saccostrea palmula and Austinotheres angelicus: Variation of the Condition Index (CI) according to the infestation categories ( 0 : not infested; $\mathrm{M}$ : male infestation; F: infestation of adult females without embryos; OF: infested by ovigerous females; $\mathrm{F}+\mathrm{M}$ : infested by adult females without embryos together with males; $\mathrm{OF}+\mathrm{M}$ : infested by ovigerous females with males) in Punta Morales, Pacific coast of Costa Rica. Bars show standard error.

\section{Discussion}

This study proved that the infestation by $A$. angelicus presents negative effects on $S$. palmula. Changes in prevalence, however, can be associated with different factors. Future studies, which should include environmental factors as well as host availability, may allow a better understanding of prevalence changes of this pea crab. 
Recently, Campos and VargasCastillo (2014) demonstrated that Cabrera et al. (2001b) most probably worked with Austinotheres angelicus, not Juxtafabia muliniarum. During 1998 and 1999, Cabrera et al. (2001b) studied the reproductive biology of $A$. angelicus as well as the aspects of its association with Saccostrea palmula in Punta Morales, the same sampling location as in this study. These authors reported a prevalence of close to $19 \%$, a value much lower than the $36.7 \%$ encountered in our study. An increase in prevalence may indicate an increase in the host's tolerance to infestation; however, this may also be interpreted as false commensalism (Miller et al., 2006). These authors also pointed out that an increase in prevalence might be associated with the vulnerability of the host.

The intensity of the infestation of bivalves by pinnotherids can change with time (Sun et al., 2006). The presence of single pinnotherids seems to be more common: Sun et al. (2006) reported an intensity of $1.18 \pm$ 0.12 Pinnotheres sinensis individuals per mussel Mytilus galloprovinciales in China, which is only slightly lower than the value observed in the present study $(1.62 \pm 0.53 \mathrm{crab} /$ oyster $)$. Cabrera et al. (2001b) found predominately single female crabs $(60 \%)$ in S. palmula. In contrast, our data indicate predominance (63\%) of oysters infested by crab couples. The pairing process in pinnotherid crabs may be associated with chemical communication, which may facilitate the encounter of female crabs (Derby and Atema, 1980; Grove and Woodin, 1996). A high prevalence increases the probability of the encounter between a male and a female occupying an oyster.

Our results suggest the association between host and symbiont is not facilitated by the oyster frequency of a specific depth, but oyster depth seems to be an important aspect in determining the colonization success of $A$. angelicus (Tab. 1). However, none of these factors can satisfactorily explain the variation of prevalence. It has been suggested that female pinnotherids randomly search a bivalve host (Haines et al., 1994), and the success of the symbiosis depends principally on previous colonization by pinnotherid crabs of the opposite sex (Haines et al., 1994), and habitat traits, such as space and food availability (Mercado-Silva, 2005; Ocampo et al., 2012). Therefore, well-designed laboratory experiments may provide more detailed insights related to the colonization process (Haines et al., 1994).

Several authors (Kruczynski, 1972; 1975; Silas and Alagarswami, 1967; Bierbaum and Ferson, 1986; Bierbaum and Shumway, 1988) suggested that pinnotherid crabs have a parasitic association with bivalves: Kruszynski (1972) studied the association between Tumidotheres maculatus (Say, 1818) and the scallop Argopecten irradians concentricus (Say, 1822), and described negative effects regarding biomass and morphology of the host species. According to Kruszynski (1975), the reason for the host's size reduction is the type of food uptake presented by the crab, in which it utilizes its chelae to feed on mucus and other particles filtered by the bivalve, thus diminishing the food availability and altering growth. Such a relationship can be considered as kleptoparasitism, since the host is affected by the reduction of food availability and not by damage directly caused by the pea crab (Iyengar, 2008). In contrast, other studies demonstrated the damage produced by pinnotherid crabs on their hosts (Silas and Alagarswami, 1967; Bierbaum and Ferson, 1986; Bierbaum and Shumway, 1988). Also, the presence of T. maculatus in Mytilus edulis Linnaeus, 1758 can provoke gill injuries and a reduction of both filtration rate and oxygen consumption of its host (Bierbaum and Ferson, 1986; Bierbaum and Shumway, 1988). Taken into account these observations, $A$. angelicus cannot be considered as a kleptoparasite since we observed deformation on gills in infested oysters during laboratory examination. According to our CI values, the presence of $A$. angelicus, mainly in pairs, significantly reduced the flesh production of $S$. palmula. Our observations demonstrate that decreases in the CI are associated with the sex and number of crabs occupying the oyster.

The results did not indicate a significant decrease in the CI of bivalves infested exclusively by males. Also, our results did not 
reveal significant differences between the CI of not infested oysters and those associated with a single ovigerous female. This finding, however, might be influenced by the fact that we found only two cases of such an infestation (Tab. 2). It seems comprehensible that female pea crabs cause a more significant CI reduction than males, considering the substantially larger size of female crabs (Sun el al., 2006).

\section{Conclusions}

Our results revealed that both number and sex of $A$. angelicus could negatively influence the CI of the infested oysters (Tab. 2; Fig. 4). Pea crab intensity seems to play an important role in determining the type of interaction between host and symbiont: with an increasing intensity of infestation, commensalism gradually transforms into parasitism (Zapalski, 2011).

In the present study, single males did not exert a statistically significant effect on its host; however, and despite of the lack of significance, single males still caused a CI reduction of $11 \%$ (Tab. 2), indicating their potential of negatively affecting the condition of $S$. palmula. Therefore, because male $A$. angelicus are occasional symbionts, they may be considered as facultative parasites. In contrast, female $A$. angelicus are obligate parasites, because they undergo a transformation after infesting the host and starting to produce offspring: the enlargement of the brood pouch with the developing embryos (Salas-Moya et al., 2014) and the softening of its body impede it from leaving the bivalve (Silas and Alagarswami, 1967).

ACKNOWLEDGEMENTS - We would like to thank to the Estación Nacional de Ciencias Marino-Costeras (ECMAR) for providing logistic support during the field trips. Special thanks go to Rita Vargas, Andrés Beita, and Gustavo Arias for their comments and collaboration during the study. Thanks to Raquel Romero Chavez for preparing the map with the sampling locations. We are grateful to Tayler Clarke for the careful linguistic revision of the manuscript. We are also thankful for the valuable comments of two anonymous referees, which enriched the final version of the manuscript.

\section{REFERENCES}

Austin, H.; Haven, D.S. and Moustafa, M.S. 1993. The relationship between trends in a condition index of the American oyster, Crassostrea virginica, and enviromental parameters in three Virginia estuaries. Estuaries, 16(2): 362-374.
Baeza, J.A. 1999. Indicadores de monogamia en el cangrejo comensal Pinnixa transversalis (Milne Edwards \& Lucas) (Decapoda: Brachyura: Pinnotheridae): distribución poblacional, asociación macho-hembra y dimorfismo sexual. Revista de Biologia Marina y Oceanografía, 34(2): 303-313.

Bierbaum, R.M. and Ferson, S. 1986. Do symbiotic pea crabs decrease growth rate in mussels? Biological Bulletin, 170: 51-61.

Bierbaum, R.M. and Shumway, S.E. 1988. Filtration and oxygen consumption in mussels, Mytilus edulis, with and without pea crabs, Pinnotheres maculatus. Estuaries, 11(4): 264-271.

Brugnoli Olivera, E. and Morales Ramírez, A. 1999. Parámetros físico-químicos de la columna de agua, en la zona de Punta Morales, Golfo de Nicoya, durante un evento "El Niño". Tópicos Meteorológicos y Oceanográficos, 6(2): 52-57.

Cabrera Peña, J.H.; Protti Quesada, M.; Urriola Hernández, M. and Saénz Vargas, O. 2001a. Crecimiento y madurez sexual de una población de Saccostrea palmula (Mollusca: Bivalvia), Costa Rica. Revista Biología Tropical, 49(3-4): 877-882.

Cabrera Peña, J.H.; Protti Quesada, M.; Urriola Hernández, M.; Saénz Vargas, O. and Alfaro Hidalgo, R. 2001b. Tallas y fecundidad de Juxtafabia muliniarum (Brachyura: Pinnotheridae) asociado con Saccostrea palmula (Mollusca: Bivalvia), Costa Rica. Revista de Biología Tropical, 49(3-4): 889-894.

Campos, E. 1990. Calypotraeotheres, a new genus for the limpet crab Fabia granti Glassell, 1933 (Crustacea, Brachyura). Proceedings of the Biological Society of Washington, 103(2): 364-371.

Campos, E. 1996. Partial revision of pinnotherid crab genera with a two-segmented palp on the third maxilliped (Decapoda: Brachyura). Journal of Crustacean Biology, 16(3): 556-563.

Campos, E. 2002. Two new genera of pinnotherid crabs from the tropical Easter pacific (Decapoda: Brachyura: Pinnotheridae). Journal of Crustacean Biology, 22(2): 328-336.

Campos, E. and Vargas-Castillo, R. 2014. Austinotheres angelicus (Lockington, 1877): the correct name for the symbiotic crab Juxtafabia muliniarum sensu Cabrera-Peña et al. (2001) (Crustacea, Brachyura, Pinnotheridae). Latin American Journal of Aquatic Research, 42(3): 598-603.

Derby, C.D. and Atema, J. 1980. Induced host odor attraction in the pea crab Pinnotheres maculates. Biological Bulletin, 158: 26-33

Feldmann, R.M.; Mackinnon, D.I.; Endo, K. and Chirino-Galvez, L. 1996. Pinnotheres laquei Sakai (Decapoda: Pinnotheridae), a tiny crab commensal within the Brachiopod Laqueus rubellus (Sowerby) (Terebratulida: Laqueidae). Journal of Paleontology, 70(2): 303-311.

Filgueira, R.; Comeau, L.A.; Landry, T.; Grant, J.; Guyondet, T. and Mallet, A. 2013. Bivalve condition index as an indicator of aquaculture intensity: A meta-analysis. Ecological Indicators, 25: 215-229.

Froese, R. 2006. Cube law, condition factor and weightlength relationships: history, meta-analysis and recommendations. Journal of Applied Ichthyology, 22: 241-253.

Geiger, D.L. and Martin, J.W. 1999. The pea crab Orthotheres haliotidis new species (Decapoda: Brachyura: Pinnotheridae) in the Australian abalone Haliotis asinina Linnaeus, 1758 and Haliotis squamata Reeve, 1846 (Gastropoda: Vetigastropoda: Haliotidae). Bulletin of Marine Science, 64(2): 269280. 
Grove, M.W. and Woodin, S.A. 1996. Conspecific recognition and host choice in a pea crab, Pinnixa chaetopterana (Brachyura: Pinnotheridae). Biological Bulletin, 190: 359-366.

Haines, C.M.C.; Edmunds, M. and Pewsey, A.R. 1994. The pea crab, Pinnotheres pisum (Linnaeus, 1967), and its association with the common mussel, Mytilus edulis (Linnaeus, 1758), in the Solent (UK). Journal of Shellfish Research, 13(1): 5-10.

Harry, H.W. 1985. Synopsis of the supraspecific classification of living oysters (Bivalvia: Gryphaeidae and Ostreidae). The Veliger, 28(1): 121-158.

Iyengar, E.V. 2008. Kleptoparasitic interactions throughout the animal kingdom and a re-evaluation, based on participant mobility, of the conditions promoting the evolution of kleptoparasitism. Biological Journal of the Linnean Society, 93: 745762.

Kruczynski, W.L. 1972. Effect of the pea crab, Pinnotheres maculatus Say, on growth of the Bay Scallop, Argopecten irradians concentricus (Say). Chesapeake Science, 13(3): 218-220.

Kruczynski, W.L. 1975. A radioactive tracer study of food uptake by Pinnotheres maculatus in molluscan hosts. Biological Bulletin, 148: 60-67.

Lemaitre, R. and Álvarez León, R. 1992. Crustáceos decápodos del Pacífico colombiano: Lista de especies y consideraciones zoogeográficas. Anales del Instituto de Investigaciones Marinas de Punta Betin, 21: 33-76.

Loosanoff, V.L. and Nomejko, C.A. 1949. Growth of oysters, $O$. virginica, during different months. The Biological Bulletin, 97(1): 82-94.

Mantelatto, F.L. and Cuesta, J.A. 2010. Morphology of the first zoeal stage of the commensal southwestern Atlantic crab Austinixa aidae (Righi 1967) (Brachyura: Pinnotheridae), hatched in the laboratory. Helgoland Marine Research, 64(4): 343348.

Mercado-Silva, N. 2005. Condition index of the eastern oyster, Cassostrea virginica (Gmelin, 1791) in Sapelo Island Georgia-Efects of site, position on bed and pea crab parasitism. Journal of Shellfish Research, 24(1): 121-126.

Miller, M.R.; White, A. and Boots, M. 2006. The evolution of parasites in response to tolerance in their host: The good, the bad, and apparent commensalism. Evolution, 60(5): 945-956

Ng, P.K.L. and Manning, R.B. 2003. On two new genera of pea crabs parasitic in holothurians (Crustacea: Decapoda: Brachyura: Pinnotheridae) from the Indo-West Pacific, with notes on allied genera. Proceedings of the Biological Society of Washington, 116(4): 901-919.

Ocampo, E.H.; Nuñez, J.D.; Cledón, M. and Baeza, J.A. 2012. Host-specific reproductive benefits, host selection behavior and host use pattern of pinnotherid crab Calyptraeotheres garthi. Journal of Experimental Marine Biology and Ecology, 429: 3646.

Peiró, D.F. and Mantelatto, F.L. 2011. Population dynamics of the pea crab Austinixa aidae (Brachyura, Pinnotheridae): a symbiotic of the ghost shrimp Callichirus major (Thalassinidea, Callianassidae) from the southwestern Atlantic. Iheringia, Série Zoologia, 101(1-2): 5-14.

Rathbun, M.J. 1900. Synopses of North-American invertebrates. XI. The catometopous or grapsoid crabs of North America. The American Naturalist, 34(403): 583-592.
Salas-Moya, C.; Mena, S. and Wehrtmann, I.S. 2014 Reproductive traits of the pea crab Austinotheres angelicus (Crustacea, Pinnotheridae) living in Saccostra palmula (Bivalvia, Ostreidae), Pacific coast of Costa Rica. Zookeys, 457: 239-252.

Silas, E.G. and Alagarswami, K. 1967. On an instance of parasitisation by the pea-crab (Pinnotheres sp.) on the backwater clam (Meretrix casta (Chemnitz)) from India with a review of the work on the systematics, ecology, biology and ethology of the pea crabs of the genus Pinnotheres Latreille. Proceedings of the Symposium on Crustacea, 3: 1161-1227.

Sun, W.; Sun, S.; Yuqi, W.; Baowen, Y. and Weibo, S. 2006. The prevalence of the pea crab, Pinnotheres sinenis, and its impact of the condition of the cultured mussel, Mytilus galloprovincialis, in Jiaonan waters (Shandong Province, China). Aquaculture, 253: 57-63.

Trottier, O.; Walker, D. and Jeff, A.G. 2012. Impact of the parasitic crab Pinnotheres novaezelandiae on aquacultured New Zeland green-lipped mussels, Perna canaliculus. Aquaculture, 344-346: 23-28.

Zapalski, M.K. 2011. In absence of proof a proof of absence? Comments on commensalism. Palaeogeography, Palaeoclimatology, Palaeoecology, 302: 484-488. 